\title{
Synthesis and Properties of Oligomers Containing 3-Triethylsilyl-1-silacyclopent-3-ene and Borane Derivatives via Polyaddition Reaction
}

\author{
Jung Hwan Lee and Young Tae Park \\ Department of Chemistry, Keimung Vniversity, Daegu 704-701. Korea \\ Received February 20.2004
}

\begin{abstract}
Polyaddition reactions of 1.1-diethy'nyl-3-triethylsilyl-1-silacyclopent-3-ene with several organoborane derivatives have afforded the oligomeric materials containing organosilacyclic group and organoboron moiety along the oligomer main chains. All of these materials are soluble in THF as well as chloroform. and their molecular weights are in the range of 1.990/1.190-21.950/7.050 $\left(\mathrm{M}_{\mathrm{w}} / \mathrm{h} / \mathrm{H}\right)$ with the polydispersity indexes of 1.67-3.43. The prepared oligomers are characterized by several spectroscopic methods such as ${ }^{1} \mathrm{H} .{ }^{13} \mathrm{C} .{ }^{29} \mathrm{Si}$. ${ }^{11} \mathrm{~B}$ NMR and FTIR spectra along with elemental analy'sis. FTIR spectra of all the oligomers show that the new strong $\mathrm{C}=\mathrm{C}$ stretching frequencies appear at $1599-1712 \mathrm{~cm}^{-1}$. in particular. The UV-vis absorption spectra of the materials in THF solution exhibit the strong absorption bands at the $\dot{\lambda}_{\text {niax }}$ of $268-275 \mathrm{~nm}$. The oligomeric materials show that the strong excitation peaks appear at the $\lambda_{\text {maix }}$ of 255-279 $\mathrm{nm}$ and the strong fluorescence emission bands at the $\lambda_{\text {max }}$ of $306-370 \mathrm{~nm}$. All the spectroscopic data suggest that the obtained materials contain both the organoboron $\pi$-conjugation moiety of $\mathrm{C}=\mathrm{C}-\mathrm{B}-\mathrm{C}=\mathrm{C}$ and the organosilacy'clic group of 3-triethylsily'1 -silacyclopent-3-ene along the oligomer main chains. The oligomers are thermally stable up to $162-200^{\circ} \mathrm{C}$ under nitrogen.
\end{abstract}

Key Words : Boron-bearing oligocarbosilanes, 3-Triethylsily1-1-silacyclopent-3-ene. Boration polymerization. Electronic and thermal properties

\section{Introduction}

Polycarbosilanes bearing $\pi$-conjugated groups in the polymer main chains have attracted a great deal of recent attention as their potential applications such as photonic. electronic, and ceranic materials. ${ }^{1}$ In this sense. considerable research effort has been devoted to develop new polycarbosilanes containing conjugation moieties. For example. diacetylene-containing polycarbosilanes showed the conductivity of $10^{-5}-10^{-3} \mathrm{~S} / \mathrm{cm}$ when doped with $\mathrm{FeCl}_{3}$. and pyrolysis of the polycarbosilanes in inert atmosphere resulted in a $\beta$-SiC ceramic materials in high yield. ${ }^{3.3}$ Recently, a series of oligomers composed of alternating 2,5bis(ethynylenedimethylsilylene)thienylene and arylene units in the main chain have been prepared by a cross-coupling reaction. ${ }^{4}$ We also reported the preparation and excited-state energy dynamics of polycarbosilanes as well as polycarbogermanes containing 1,4-bis(thiophene or phenylene)buta1,3-diyne in the polymer backbone. ${ }^{5-8}$

Organosilacyclic compounds such as 1-silacyclopent-3enes have also received much concen in the field of organosilicon chemistry. ${ }^{9-11}$ For instance, 1.1-dimethyl-1silacyclopent-3-ene undergoes anionic ring-opening polymerization by reaction with alkyllithium and hexamethylphosphoramide (HMPA) at $-78^{\circ} \mathrm{C}$ to yield polycarbosilane such as poly (1.1-dimethyl-1-sila-cis-pent-3-ene). ${ }^{12}$ Recently. we also reported the preparation of polycarbosilanes containing diacetylenic and organosilacyclic groups along the polymer main chain such as poly(1,1-diethynyl-1-

\footnotetext{
Comesponding author. E-mail: ytparkiakmu.ac.kr
}

silacyclopent-3-enes and -1-silacyclobutane) using oxidative coupling polymerization and their electronic properties. ${ }^{13}$

Organoborons are useful reagents for the preparation of a variety of functional compounds in organic synthesis. ${ }^{14}$ From this point of view. polymeric homologues of organoboron compounds may have a potential to exhibit unique properties as novel polymeric materials. Meanwhile, Chujo have reported the various preparations of organoboron polymers consisting of $\mathrm{C}-\mathrm{B}$ bonds in the main chain by several polyaddition reactions between organic diynes and borane derivatives. ${ }^{15.16}$ Chujo have also reported that a series of $\pi$-conjugated organoboron polymer were synthesized by polyaddition using boration reaction and the extension of the $\pi$-conjugation length via the boron atom was observed in the organoboron main chain. ${ }^{17.18}$ However, boration polymerizations between organosilicon diynes and borane derivatives have scarcely been reported.

Since we have successfully prepared diyne-containing silacyclic monomer such as 1.1-diethynyl-3-triethylsilyl-1silacyclopent-3-ene and applied to a coupling polymerization. ${ }^{13.19}$ we have also been interested in the preparation and properties of polycarbosilanes containing organoboron group along the polymer backbone by utilizing boration polymerization of 1,1-diethynyl-1-silacyclopentene derivatives. Furthermore, the organoborane-bearing polycarbosilane materials synthesized can be expected to include a novel $\pi$-conjugated moiety of $\mathrm{C}=\mathrm{C} \cdot \mathrm{B}-\mathrm{C}=\mathrm{C}$ and the organosilacyclic group of 3-triethylsilyl-1-silacyclopent-3-ene along the polymer main chains. Herein. we wish to report the polyaddition reaction of 1.1-diethynyl-3-triethylsilyl-1silacyclopent-3-ene with several organoborane derivatives 
We also describe the electronic and thermal properties of the prepared oligocarbosilanes containing organoborane group.

\section{Results and Discussion}

Synthesis of Oligomers. 1,1-Diethynyl-3-triethylsilyl-1silacycloepnt-3-ene (1) was prepared by ethynylation reaction of 1,1-dichloro-3-triethylsilyl-1-silacyclopent-3-ene with ethynylmagnesium chloride as the previously reported method by our research group. ${ }^{1.3}$ The monomer 1 was characterized using several spectroscopic methods such as ${ }^{1} \mathrm{H},{ }^{1.3} \mathrm{C}$, and ${ }^{26} \mathrm{Si} N M \mathrm{R}$ as well as IR spectra. In the IR spectrum of 1 , the characteristic acetylenic $C \equiv C$ and ring vinyl $\mathrm{C}=\mathrm{C}$ stretching frequencies are observed at 2050 and $1570 \mathrm{~cm}^{-1}$, respectively. The 'H NMR spectrum of 1 shows that the singlet resonance appears at $2.51 \mathrm{ppm}$ for ethynyl $(\mathrm{C} \equiv \mathrm{CH})$ protons and the triplet at $6.15 \mathrm{ppm}$ for vinyl $(\mathrm{C}=\mathrm{CH})$ proton on the ring. In the ${ }^{13} \mathrm{C}$ NMR spectrum of $\mathrm{I}$, eight carbon peaks appear at 2,63, 7.29, 20,87, 21,16,84.08. $95.74,139.37$, and $141.34 \mathrm{ppm}$, where the resonances assigned to the ethynyl carbons are observed at 84.08 and $95.74 \mathrm{ppm}$, and ones assigned to the vinyl carbons at 139.37 and $141.34 \mathrm{ppm}$. The ${ }^{2 \mathrm{it}} \mathrm{Si}$ NMR spectrum of 1 exhibits that two silicon peaks appear at 0.07 and $-28.72 \mathrm{ppm}$.

Boration polymerizations between organic diynes and various borane derivatives such as haloborane, akylborane, and phenylborane have been extensively reported to yield $\pi$ conjugated organoboron polymers by Chujo research team, ${ }^{15-18}$ We tried the same polymerization technique by utilizing the functionality of diethynyl-containing compound 1 as novel monomer. The polyaddition reactions of 1 with several borane derivatives 2a-f have been carried out to afford the novel materials 3a-f in moderate yields, respectively, which contain $\mathrm{C}=\mathrm{C}-\mathrm{B}-\mathrm{C}=\mathrm{C}$ moiety as well as organosilacyclic groups in the polymer main chain, as shown in Scheme 1 .

The boron-bearing polycarbosilanes 3a-f obtained as dark brown powder or yellowish viscous gel are soluble in usual organic solvents such as $\mathrm{CHCl}_{3}$ and THF. By running gel permeation chromatography $\left(\mathrm{GP}^{\mathrm{C}} \mathrm{C}\right)$ we measured molecular weights of $\mathbf{3 a - f}$ which turned out to be oligomers with molecular weights ranging $1,990 / 1,190-21,950 / 7,050\left(\mathrm{M}_{1} /\right.$ $\left.M_{t}\right)$ and to have broad molecular weight distributions with the polydispersity indexes of 1.67-3.43, as shown in Table 1. The broad molecular weights distributions might be ascribed to the copolymerization technique applied in this research by using the two different types of monomers. ${ }^{20}$

We tried to characterize the oligomers 3a-f by several spectroscopic methods. The structures of $\mathbf{3 a}-\mathbf{f}$ were supported by ${ }^{1} \mathrm{H},{ }^{1.3} \mathrm{C}$, ${ }^{20} \mathrm{Si},{ }^{1 /} \mathrm{B} \mathrm{NMR}$, and IR spectra as well as elemental analysis. Some selected spectral properties of the oligomers $\mathbf{3} \mathbf{a}-\mathbf{f}$ are summarized in Table 1 .

In the FTIR spectra of all the oligomers 3a-f, the characteristic $\mathrm{C} \equiv \mathrm{C}$ stretching frequency of 1 at $2050 \mathrm{~cm}^{-1}$ almost disappeared and the $\mathrm{C}=\mathrm{C}$ stretching frequencies in the silacyclopentene ring of 1 remained intact at 1570-1602 $\mathrm{cm}^{-1}$, while the new strong $\mathrm{C}=\mathrm{C}$ stretching frequencies appeared at $1599-1712 \mathrm{~cm}^{-1}$, indicating that the $\mathrm{C}=\mathrm{C}$ bonds along the oligomer backbones were newly formed during polyaddition reactions. ${ }^{21.22}$

In the ' $\mathrm{H}$ NMR spectra of 3a-f in $\mathrm{CDCl}_{3}$, ethynyl protons of 1 at 2.51 ppm disappeared and the vinyl proton on the silacyclopentene ring of 1 remained intact at $6.14-6.50 \mathrm{ppm}$, while the new vinyl protons appeared at $5.28-5.90 \mathrm{ppm}$, which is consistent with the proposed structure of oligomers 3a-f. The ${ }^{1 /} \mathrm{C}$ NMR of 3a-f show that the ethynyl $\mathrm{C} \equiv \mathrm{C}$ carbon resonances of 1 at 84.08 and 95.74 ppm disappeared and the vinyl $\mathrm{C}=\mathrm{C}$ carbon peaks in the silacyclopentene ring of 1 remained intact at $130.87-141.71 \mathrm{ppm}$, while the new viny] $C=C$ carbon resonances appeared at $128.77-140.00$ ppm, which is also consistent with the proposed structure of oligomers $3 \mathbf{a}-\mathbf{f}$. The structures of oligomers $\mathbf{3} \mathbf{a}-\mathbf{f}$ were also confirmed by the " $\mathrm{Si}$ and ${ }^{11} \mathrm{~B}$ NMR spectra of all the prepared oligomers, as shown in Table 1. In the case of the polyadditions of dichlophenylborane (2e) and dichlorobutylborane (2f), haloboration reactions occurred to yield corresponding oligomers $3 \mathrm{e}$ and $\mathbf{3 f}$, respectively, due to the higher reactivity of halogen atom such as chlorine than that of phenyl or butyl groups.

Properties of Oligomers. All oligomers 3a-f were soluble in common organic solvents such as [HH and chloroform.<smiles>C#C[Si]1(C#C)CC=C([SiH2]C)C1</smiles>

1

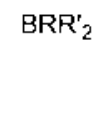

2a $: R, R^{\prime}=\mathrm{Br}$
2b: $\mathrm{R}, \mathrm{R}^{\prime}=\mathrm{Cl}$
2c $: \mathrm{R}, \mathrm{R}^{\prime}=n-\mathrm{Bu}$
2d $: \mathrm{R}, \mathrm{R}^{\prime}=\mathrm{Ph}$
2e $: \mathrm{R}=\mathrm{Ph}, \mathrm{R}^{\prime}=\mathrm{Cl}$
$\mathbf{2 f}: \mathrm{R}=n-\mathrm{Bu}, \mathrm{R}^{\prime}=\mathrm{Cl}$

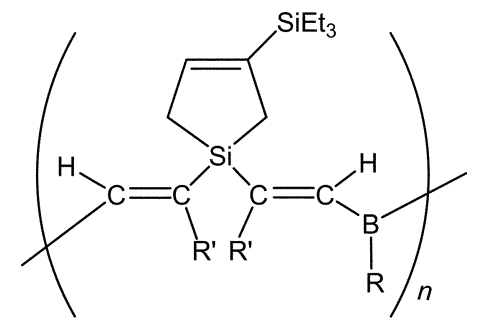

$3 a: R, R^{\prime}=\operatorname{Br}(61 \%)$

$3 b: R, R^{\prime}=\mathrm{Cl}(65 \%)$

$3 c: R, R^{\prime}=n-B u(36 \%)$

3d : $R_{1} R^{\prime}=P h(27 \%)$

3e : $R=P h, R^{\prime}=C l(81 \%)$

3f : $\mathrm{R}=\mathrm{n}-\mathrm{Bu}, \mathrm{R}^{\prime}=\mathrm{Cl}(65 \%)$

Scheme 
Table 1. Selected Propertics of the Oligomers $3 \mathbf{a}-\mathbf{f}$

\begin{tabular}{|c|c|c|c|c|c|c|c|c|}
\hline Oligomer & $\begin{array}{l}H_{11} / M_{, r} \\
(\mathrm{PIOH})\end{array}$ & $\begin{array}{c}{ }^{2 "} \mathrm{Si} \mathrm{NMR}{ }^{\prime \prime} \\
\delta(p p m)\end{array}$ & $\begin{array}{l}\text { "I3 } \mathrm{NMR}^{\prime \prime} \\
\delta(\Gamma \mathrm{M})\end{array}$ & $\begin{array}{c}\mathrm{IR}^{c} \\
v_{4}\left(\mathrm{c}_{1}\left(\mathrm{~cm}^{-1}\right)\right.\end{array}$ & $\begin{array}{l}\text { Absorption } \\
\lambda_{\tan }(\mathrm{nm})\end{array}$ & $\begin{array}{l}\text { Excitation } \\
\lambda_{\operatorname{man}}(\mathrm{nm})\end{array}$ & $\begin{array}{c}\text { Fluorescence } \\
\lambda_{\text {Itras }}(\text { nm) }\end{array}$ & $\operatorname{TG} A^{k}$ \\
\hline $3 a$ & $\begin{array}{c}4.29011 .250 \\
(3.43)\end{array}$ & 0.03 .19 .09 & 4.04 & 1712 & 271 & 277 & 310 & 68 \\
\hline $3 \mathbf{b}$ & $\begin{array}{c}4.140 .1 .260 \\
(3.29)\end{array}$ & 0.01 .23 .12 & -3.78 & 1710 & 269 & 277 & 311 & 83 \\
\hline $3 c$ & $\begin{array}{c}7.1802 .100 \\
(3.42)\end{array}$ & $-0.45,-21.95$ & -3.80 & 1711 & 269 & 276 & 306 & 87 \\
\hline $3 d$ & $\begin{array}{c}21.950 / 7.050 \\
(3.11)\end{array}$ & $-0.45 .-5.85$ & 12.29 & 1599 & 275 & 279 & 326 & 66 \\
\hline $3 e$ & $\begin{array}{c}1.990 / 1.190 \\
(1.67)\end{array}$ & 0.00 .8 .87 & -3.96 & 1711 & 269 & 272 & 344 & 76 \\
\hline $3 f$ & $\begin{array}{c}3.720 / 1.920 \\
(1.93)\end{array}$ & $0.00 \cdot 19.74$ & -2.49 & 1709 & 268 & 255 & 370 & 64 \\
\hline
\end{tabular}

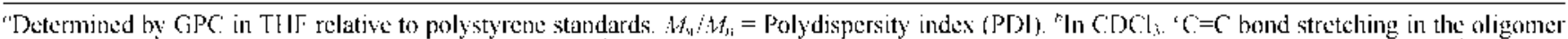
main chain and measured by neal or DRIFT method. "UV-vis absorption in TIIF. "Detection wavelength at 310 or $340 \mathrm{~nm}$ in TI IF. "Excitation wavelength at $275 \mathrm{~mm}$ in THF, $\%$ Weight remaining at 400 "C under nitrogen.

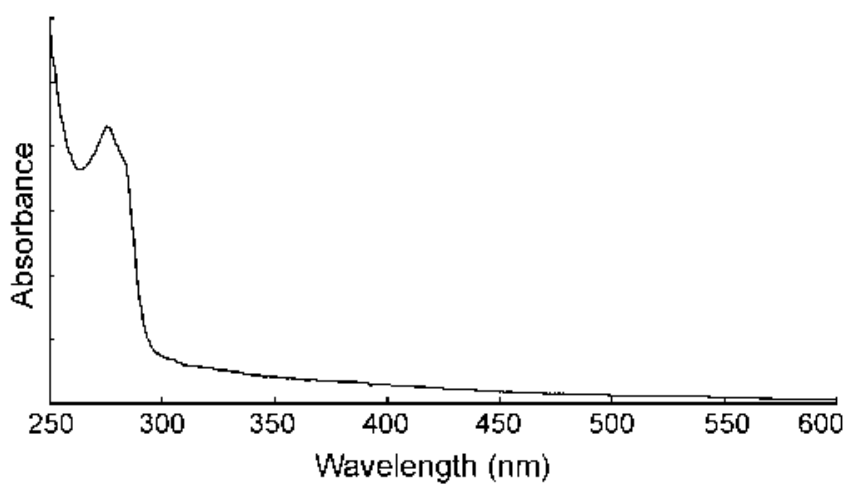

Figure 1. UV-vis absorption spectrum of the oligomer $\mathbf{3 a}$ in THF.

The solubility of $\mathbf{3 a - f}$ allows us to perform studies on the properties in solution. The typical UV-vis absorption spectrum of $\mathbf{3} \mathbf{a}$ in [HF has been shown in Figure 1 , where the maximum absorption band at $27 \mathrm{Im}\left(\varepsilon=1.43 \times 10^{5} \mathrm{M}^{-1}\right.$ $\mathrm{cm}^{-1}$ ) with broad and weak tailing between 264 and $57 \mathrm{lmm}$ is observed. For oligomers $\mathbf{3} \mathbf{a}-\mathbf{f}$ the strong absorption bands are observed at the $\lambda_{\text {rnax }}$ of $268-275 \mathrm{~nm}$, as listed in lable 1 . which are probably due to the presence of $\mathrm{C}=\mathrm{C}-\mathrm{B}-\mathrm{C}=\mathrm{C}$ chromophore along the oligomer backbone..$^{2.3}$

The typical excitation spectrum for $\mathbf{3 a}$ at the detection wavelength of $310 \mathrm{~nm}$ in $\mathrm{THF}$ exhibits the strong excitation band at the $\lambda_{\max }$ of $277 \mathrm{~nm}$, as shown in Figure 2. As outlined in Table 1 , the excitation spectra of $\mathbf{3 b} \mathbf{b} \mathbf{f}$ at the detection wavelength of 310 or $340 \mathrm{~nm}$ in $1 \mathrm{HH}$ show that the strong excitation peaks appear at the $\lambda_{\text {miar }}$ of $255-279 \mathrm{~nm}$, which are probably attributable to $\mathrm{C}=\mathrm{C}-\mathrm{B}-\mathrm{C}=\mathrm{C}$ group along the oligomer chain.

The typical fluorescence emission spectrum of $3 \mathbf{a}$ at the excitation wavelength of $275 \mathrm{~nm}$ also exhibits the strong emission peak at the $\lambda_{\text {max }}$ of $310 \mathrm{~nm}$ with the broad emission band of 281-556 nm, as shown in Figure 2. As indicated in lable 1 , the fluorescence emission spectra of $\mathbf{3 b - f}$ at the excitation wavelength of $275 \mathrm{~nm}$ in ' $\mathrm{HHF}$ reveal that the

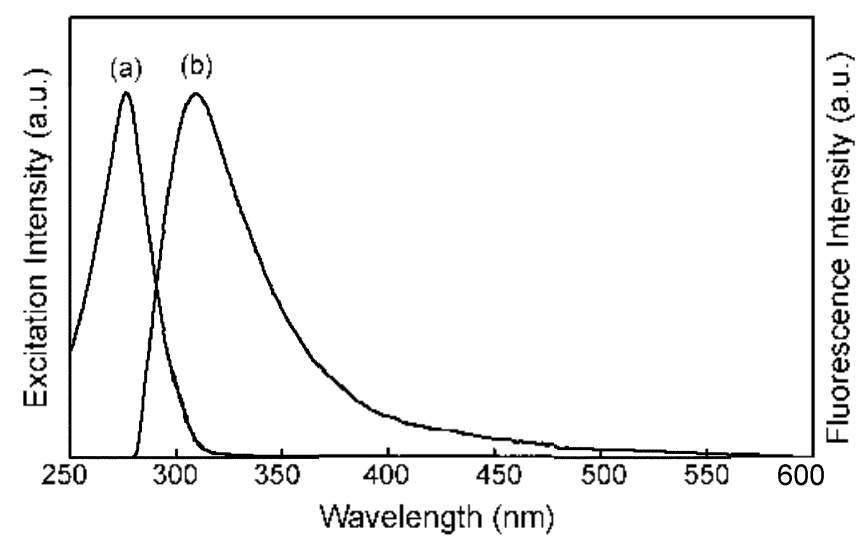

Figure 2. Excitation (line (a). $\lambda_{\text {det }}=310 \mathrm{~nm}$ ) and fluorescenes (line (b). $\lambda_{\mathrm{e}} 275 \mathrm{~mm}$ ) spectra of the oligomer $\mathbf{3 a}$ in THF.

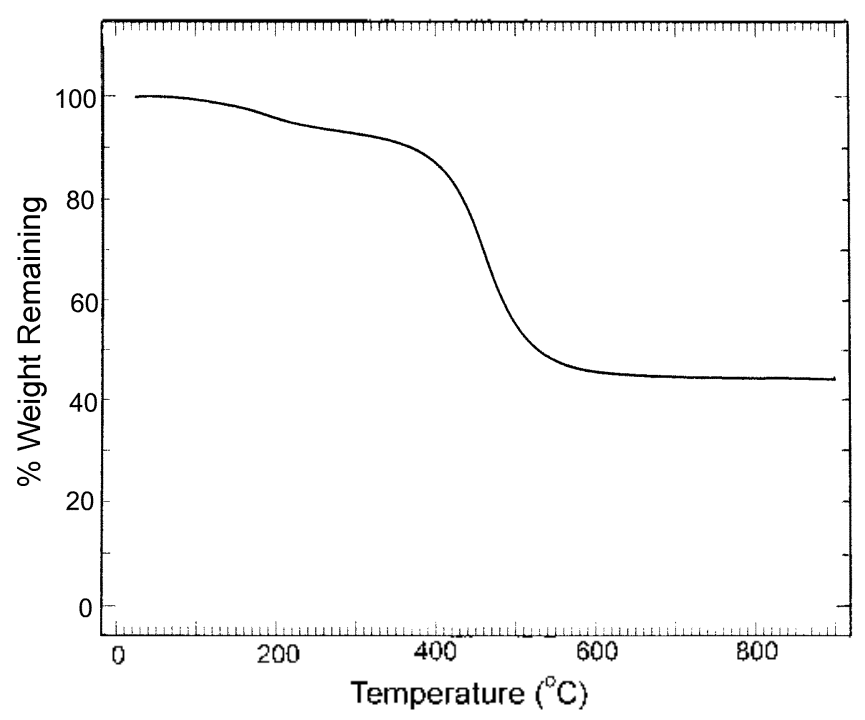

Figure 3. TGA thermogram of the oligomer 3e under nitrogen.

strong fluorescence emission peaks appear at the $\lambda_{\max }$ of $306-370 \mathrm{~nm}$, which are probably ascribed to the fluorophore 
of $\mathrm{C}=\mathrm{C} \cdot \mathrm{B}-\mathrm{C}=\mathrm{C}$ along the oligomer chain. ${ }^{\mathrm{i}}$

Those strong absorption, excitation. and fluorescence bands of 3a-f in their corresponding spectra inply that all the prepared oligomers contain the partially delocalized $\pi$ conjugation groups of $\mathrm{C}=\mathrm{C} \cdot \mathrm{B}-\mathrm{C}=\mathrm{C}$ as well as organosilacyclic group through the oligomer main chains.

The thermal stabilities of oligomers 3a-f under nitrogen atmosphere were determined by thermogravimetric analysis (TGA) with a heating rate of $10^{\circ} \mathrm{C} / \mathrm{min}$. The typical TGA thermogram of $3 \mathbf{c}$ was shown in Figure $3.3 \mathrm{c}$ is stable up to $200{ }^{\circ} \mathrm{C}$ with weight loss of $4 \%$ only. Rapid weight loss of $46 \%$ of the initial weight occurs between 300 and $600^{\circ} \mathrm{C}$. When $3 \mathrm{c}$ is heated to $900{ }^{\circ} \mathrm{C}, 55 \%$ of the initial weight of $3 \mathrm{c}$ is lost. and about $45 \%$ char yield is observed.

Normally. the oligomers $3 \mathbf{a}-\mathbf{f}$ are thermally stable up to $162-200{ }^{\circ} \mathrm{C}$ with weight loss of only $2-10 \%$. Rapid weight loss of $16-68 \%$ of the initial weight occurs between 300 and $600{ }^{\circ} \mathrm{C}$. When the oligomers are heated to $900{ }^{\circ} \mathrm{C}$ by the heating rate of $10{ }^{\circ} \mathrm{C} / \mathrm{min}$. residues of $21-62 \%$ remain. Usually. about $64-87 \%$ of the initial polymer weights remain at $400^{\circ} \mathrm{C}$ under nitrogen atmosphere. as indicated in Table 1.

\section{Conclusion}

We have successfully prepared the oligomeric materials which contain the partially delocalized $\pi$-conjugation moiety of $\mathrm{C}=\mathrm{C}-\mathrm{B}-\mathrm{C}=\mathrm{C}$ as well as organosilacyclic group along the oligomer main chains by the polyaddition reaction of 1,1 diethynyl-3-triethylsilyl-1-silacyclopent-3-ene with several organoborane derivatives. All of these materials are soluble in THF and chloroform, and tuned out to be oligomers with molecular weights in the range of $1.990 / 1,190-21,950 / 7,050$ $\left(M_{n} / M_{n}\right)$ with the polydispersity indexes of 1.67-3.43. The FTIR spectra of all the oligomers indicate that $\mathrm{C}=\mathrm{C}$ bonds along the oligomer backbones were newly formed during the polymerization. Structures of the oligomers were also confirmed by several other spectroscopic methods such as ${ }^{1} \mathrm{H} .{ }^{13} \mathrm{C}$. ${ }^{19} \mathrm{Si}$. and ${ }^{11} \mathrm{~B}$ NMR spectra as well as elemental analysis. The oligomers are thermally stable up to $162-200$ ${ }^{\circ} \mathrm{C}$ under nitrogen. The UV-vis absorption spectra exhibit the strong absorption bands at the $\lambda_{\text {max }}$ of $268-275 \mathrm{~lm}$. The excitation spectra show that the strong excitation peaks appear at the $\lambda_{\max }$ of $255-279 \mathrm{~lm}$. The fluorescence enission spectra show that the strong emission peaks are observed at the $\lambda_{\max }$ in the range of $306-370 \mathrm{~nm}$. All the spectroscopic data strongly suggest that the obtained oligomeric materials contain both the organoboron-bearing $\pi$-conjugated moiety of $\mathrm{C}=\mathrm{C} \cdot \mathrm{B}-\mathrm{C}=\mathrm{C}$ and the organosilacyclic group of 3 triethylsilyl-1-silacyclopent-3-ene along the oligomer main chains.

\section{Experimental Section}

General Procedures. All chemicals were purchased from Aldrich Chemicals Inc. All solvents were purified prior to use according to standard literature methods: tetrallydrofuran (THF), $n$-hexane. and diethyl ether were distilled from sodium benzophenon ketyl. ${ }^{25}$ All glassware was assembled and was then flame-dried while being swept with argon. Reactions were monitored by Hewlett Packard 5890II analytical GLC equipped with HP.I capillary colunn $(0.53$ $\mathrm{mm} \times 30 \mathrm{~m}$ ) coated with cross-linked methyl silicon gum and with flame ionization detector (FID). The colunn was deactivated immediately before use by injection of $50 \mu \mathrm{L}$ of hexametlyyldisilazane. ${ }^{1} \mathrm{H}$ and ${ }^{13} \mathrm{C}$ nuclear magnetic resonance (NMR) spectroscopy were performed on a Bruker DRX Avance $400 \mathrm{MHz}$ FT-NMR spectrometers using $\mathrm{CDCl}_{3}$ as solvent. Chemical shifts were measured using tetramethylsilane as intemal standard or the residual proton signal of the solvent as standard. ${ }^{29} \mathrm{Si}$ and ${ }^{11} \mathrm{~B}$ nuclear magnetic resonance (NMR) spectroscopy were performed on a Varian Unity INOVA $500 \mathrm{MHz}$ FT-NMR spectrometer using $\mathrm{CDCl}_{3}$ as solvent at the Korea Basic Science Institute. IR spectra were recorded by a Shimadzu IR 430 spectrometer or a Bruker IFS-48 FT-IR spectrometer using DRIFT method. UV-vis absorption spectra were obtained on a Hewlett Packard 8453 spectrophotometer. Excitation and fluorescence emission spectra were obtained on a Hitachi F- 4500 fluorescence spectrophotometer. Gel permeation chromatography (GPC) analyses were performed on a Waters model 510 system with a Waters Styragel HR 3 column and refractive index detector at $25^{\circ} \mathrm{C}$. The eluent was THF at a flow rate of 1.0 $\mathrm{mL} / \mathrm{min}$. The calibration was made with a series of monodispersed poly styrene standards: $M_{\mathrm{F}} 580,3250.10100$, and 28500 whose $M_{\mathrm{r}} / M_{\mathrm{n}}$ are less than 1.2. Thermogravimetric analysis (TGA) of polymer samples was performed on a TGA-50 Shimadzu thermal analysis system. The temperature was increased at the heating rate of $10^{\circ} \mathrm{C} / \mathrm{min}$ from room temperature to $900^{\circ} \mathrm{C}$ with nitrogen flow rate of $20 \mathrm{~mL} / \mathrm{min}$. Elemental analyses were performed on a Fisons EA 1108 elemental analyzer.

1,1-Diethynyl-3-triethylsilyl-1-silacyclopent-3-ene (1) was prepared by the previously reported methods. ${ }^{13,19}$

Polyaddition Reactions of 1 with Borane Derivatives (2). A general procedure for polyaddition reactions of 1 with 2 is described as follows: In a flame dried $50 \mathrm{~mL}$ Schlenk flask with rubber septum. boron tribromide (2a) $(1.0 \mathrm{M} /$ dichloromethane. $3.73 \mathrm{~mL} .3 .73 \mathrm{mmol}$ ) was placed using a syringe under argon atmosphere. The flask was cooled to -78 ${ }^{\circ} \mathrm{C}$ using a dry ice/acetone bath. and then 1 (0.92 g. 3.37 mmol) was added with vigorous stirring. The reaction mixture was stirred for $2 \mathrm{~h}$ and allowed to warm to room temperature with well stirring. The crude oligomer was precipitated by addition of dry $n$-pentane or methanol and dried under reduced pressure. The oligomeric material $\mathbf{3 a}$. $1.15 \mathrm{~g}, 61 \%$ was obtained as a dark brown solid with $M_{\mathrm{n}} / M_{i n}$ of 4.290/1,250 (polydispersity index, PDI $=3.43$ ). ${ }^{l} \mathrm{H}$ NMR (THF- $d_{\delta} .400 \mathrm{MHz}$ ): $\delta 0.62(\mathrm{~m} .6 \mathrm{H}$ ), 0.95 (m. 9H), 1.29 (s, $4 \mathrm{H}) .5 .77$ (s. $2 \mathrm{H}) .6 .50(\mathrm{~m}, \mathrm{lH}){ }^{13} \mathrm{C}$ NMR $\left(\mathrm{CDCl}_{3} \cdot 100\right.$ $\mathrm{MHz}): \delta 2.63,6.77 .22 .96,23.60 .128 .77,129.18,130.87$. 132.35: ${ }^{29} \mathrm{Si} \mathrm{NMR}\left(\mathrm{CDCl}_{3}, 99 \mathrm{MHz}\right): \delta 0.03,19.09 ;{ }^{11} \mathrm{~B}$ NMR ( $\mathrm{CDCl}_{2} .160 \mathrm{MHz}$ ): $\delta 4.04$; IR (KBr, DRIFTS): $v$ 3219. 2965, 2911, 2877, 2261, 2043, $1712(\mathrm{C}=\mathrm{C}), 1602$, 1413. 1368, 1235, 1195. 1086. 1008,882.846.812, 743 . 
$669 \mathrm{~cm}^{-1}$; UV-vis (THF): $\lambda_{\text {max }} \operatorname{lnm}(\varepsilon) 271\left(1.43 \times 10^{5}\right)$. Anal. Calcd for $\left(\mathrm{C}_{14} \mathrm{H}_{22} \mathrm{Si}_{2} \mathrm{BBr}_{3}\right)_{5}:$ C. 33.83 ;, 4.46 . Found: $\mathrm{C}$. 33.33: H. 4.49. The excitation and fluorescence enission spectra in THF solution as well as TGA thermogram are described in Result and Discussion.

A dark brown solid 3b $(0.95 \mathrm{~g}, 65 \%)$ was obtained from 1 $(1.00 \mathrm{~g} .4 .06 \mathrm{mmol})$ and boron trichloride $(2 \mathrm{~b})(1.0 \mathrm{M} /$ dichloromethane, $4.06 \mathrm{~mL}, 4.06 \mathrm{mmol}): M_{n} / M_{n}=4.140 /$ $1,260(\mathrm{PDI}=3.29):{ }^{1} \mathrm{H} \mathrm{NMR}\left(\mathrm{CDCl}_{3 .} 400 \mathrm{MHz}\right): \delta 0.59-$ 0.61 (m. 6H), 0.86-0.99 (m. 9H). 1.57 (s, 2H), 1.85-1.87 (n. $2 \mathrm{H}), 5.28(\mathrm{~s}, 2 \mathrm{H}), 6.25(\mathrm{~m} .1 \mathrm{H}) ;{ }^{13} \mathrm{C}$ NMR $\left(\mathrm{CDCl}_{3}, 100\right.$ MHz): $\delta 2.68 .6 .79,22.68 .25 .59$. 129.25. 130.63. 131.38 . 133.13: ${ }^{{ }^{9}} \mathrm{Si} \mathrm{NMR}\left(\mathrm{CDCl}_{3}, 99 \mathrm{MHz}\right): \delta 0.01 .23 .12:{ }^{11} \mathrm{~B}$ NMR $\left(\mathrm{CDCl}_{3 .} .160 \mathrm{MHz}\right): \delta-3.78$; IR (KBr, DRIFTS): $v$ $3286,2953,2909.2876 .2732 .2367 .2042 .1710(\mathrm{C}=\mathrm{C})$. $1573,1413,1357,1236,1147,1089,1006,867,830.719$ $\mathrm{cm}^{-1}$ : UV-ris (THF): $\lambda_{\text {max }}$ nun $(\varepsilon) 269\left(7.72 \times 10^{4}\right)$. Anal. Calcd for $\left(\mathrm{C}_{1+} \mathrm{H}_{23} \mathrm{Si}_{-} \mathrm{BCl}_{3}\right)_{\text {n: }}$ : C, 46.23: H. 6.10. Found: $\mathrm{C}$. 45.31: H. 6.16. The excitation and fluorescence enission spectra in THF solution as well as TGA thermogram are described in Result and Discussion.

Oligomeric Materials 3c-f were prepared in the similar manner to that described for 3a. except that the reaction mixture was stirred at room temperature for $\mathrm{lh}$ and then warmed to reflux for overnight. A reddish yellow viscous gel $3 \mathrm{c}(0.63 \mathrm{~g} .36 \%)$ was obtained from $1(1.00 \mathrm{~g} .4 .06 \mathrm{mmol})$ and tributylborane (2c) (1.0 M/diethyl ether. $4.06 \mathrm{~mL} .4 .06$ mmol): $M_{w} / M_{n}=7,180 / 2.100(\mathrm{PDI}=3.42):{ }^{1} \mathrm{H}$ NMR $\left(\mathrm{CDCl}_{3,} 400 \mathrm{MHz}\right): \delta 0.59$ (m. $\left.8 \mathrm{H}\right), 0.88(\mathrm{~m} .19 \mathrm{H}) .1 .21-$ $1.25(\mathrm{~m}, 9 \mathrm{H}), 1.45-1.70$ (br. $8 \mathrm{H}), 1.86(\mathrm{~m}, 2 \mathrm{H}) .5 .30(\mathrm{~s}, 2 \mathrm{H})$ $6.14(\mathrm{~m} . \mathrm{HH}):{ }^{13} \mathrm{C} \mathrm{NMR}\left(\mathrm{CDCl}_{3 .} .100 \mathrm{MHz}\right): \delta 2.74 .5 .87$. $6.74,7.43 .14 .00,20.41,22.56,25.53,26.88 .29 .65 .31 .88$. 140.35. 140.52, 141.50. 141.71: ${ }^{29} \mathrm{Si} N \mathrm{NMR}\left(\mathrm{CDCl}_{3} .99\right.$ MHz): $\delta-0.45,21.95 ;{ }^{11} \mathrm{~B} \mathrm{NMR}\left(\mathrm{CDCl}_{3}, 160 \mathrm{MHz}\right): \delta-3.80$ : IR (neat): $v$ 3291. 2955. 2874. 2732. 2037, $1711(\mathrm{C}=\mathrm{C})$. 1574, 1461, 1414, 1377, 1262. 1237. 1092. 1016.861, 801, $716 \mathrm{~cm}^{-1}$; UV-vis $(\mathrm{THF}): \lambda_{\text {max }} \operatorname{lnm}(\varepsilon) 269\left(1.62 \times 10^{5}\right)$. Anal. Calcd for $\left(\mathrm{C}_{26} \mathrm{H}_{40} \mathrm{Si}=\mathrm{B}\right)_{n}: \mathrm{C} .72 .85 ; \mathrm{H}, 11.52$. Found: $\mathrm{C}$. 71.66: $\mathrm{H}, 11.40$. The excitation and fluorescence enission spectra in THF solution as well as TGA thennogram are described in Result and Discussion.

A pale yellow viscous gel $3 \mathrm{~d}(0.55 \mathrm{~g}, 27 \%)$ was obtained from 1 ( $1.00 \mathrm{~g} .4 .06 \mathrm{mmol})$ and triphenylborane (2d) $(0.25$ M/THF. $16.26 \mathrm{~mL}, 4.06 \mathrm{nmol}$ ): $M_{w} / M_{n}=21,950 / 7,050$ (PDI $=3.11):{ }^{1} \mathrm{H} \mathrm{NMR}\left(\mathrm{CDCl}_{\mathrm{j} .} .400 \mathrm{MHz}\right): \delta 0.88(\mathrm{q}, 6 \mathrm{H}), 1.26(\mathrm{t}$. $9 \mathrm{H}), 1.68(\mathrm{~s} .2 \mathrm{H}), 2.04(\mathrm{~s}, 2 \mathrm{H}), 5.28(\mathrm{~s}, 2 \mathrm{H}), 6.2 \mathrm{l}(\mathrm{m}, \mathrm{lH})$. 7.48-7.72 (n. $15 \mathrm{H}) ;{ }^{13} \mathrm{C}$ NMR $\left(\mathrm{CDCl}_{3} .100 \mathrm{MHz}\right) ; \delta 2.93$. $7.32,20.55,21.06 .122 .28$. 122.47, 125.50, 135.68. 139.42. 139.78. 140.22, 140.98, 141.48. 141.61, 141.78: ${ }^{2} \mathrm{Si} \mathrm{NMR}$ $\left(\mathrm{CDCl}_{3}, 99 \mathrm{MHz}\right): \delta-0.45,-5.85:{ }^{11} \mathrm{~B}$ NMR $\left(\mathrm{CDCl}_{3}, 160\right.$ MHz): $\delta$ 12.29: IR (neat): $v 3300,2900.2050,1599(\mathrm{C}=\mathrm{C})$. $1570,1460,1440,1410,1390,1380,1340,1280.1240$. $1150,1050.970,950,850,830.780 .720 .670 \mathrm{~cm}^{-1}$. UV-vis (THF): $\lambda_{\text {max }} \mathrm{Im}(\varepsilon) 275\left(1.12 \times 10^{4}\right)$. Antal. Calcd for $\left(\mathrm{C}_{3}-\mathrm{H}_{37} \mathrm{Si}_{3} \mathrm{~B}\right)_{\pi}:$ C. 78.66; H. 7.63. Found: C. 79.21: H, 7.65. The excitation and fluorescence emission spectra in THF solution as well as TGA thermogram are described in Result and Discussion.

A dark brown powder $3 \mathrm{e}(1.33 \mathrm{~g} .81 \%)$ was obtained from 1 (1.00 g. $4.06 \mathrm{mmol}$ ) and dichlorophenylborane (2e) $(0.65$ g. $4.06 \mathrm{mmol}): M_{\mathrm{v}} / M_{n}=1,990 / 1.190(\mathrm{PDI}=1.67) ;{ }^{1} \mathrm{H}$ NMR $\left(\mathrm{CDCl}_{3} .400 \mathrm{MHz}\right): \delta 0.55(\mathrm{~m}, 6 \mathrm{H}), 0.90-0.99(\mathrm{~m} .9 \mathrm{H}) .1 .58$ (s, $2 \mathrm{H}) .1 .88(\mathrm{~s}, 2 \mathrm{H}) .5 .90$ (br. $2 \mathrm{H}), 6.20(\mathrm{~m}, \mathrm{lH}) .7 .42-7.78$ (m. $5 \mathrm{H}):{ }^{13} \mathrm{C} \mathrm{NMR}\left(\mathrm{CDCl}_{3} .100 \mathrm{MHz}\right): \delta 2.81 .6 .80,21.25$, $26.95,125.51,127.97,128.31,129.61,130.14,130.27$. 132.70, 135.63: ${ }^{29} \mathrm{Si} \mathrm{NMR}\left(\mathrm{CDCl}_{3}, 99 \mathrm{MHz}\right): \delta 0.00,8.87$; ${ }^{13} \mathrm{~B}$ NMR (CDCl $3.160 \mathrm{MHz}$ ): $\delta-3.96$ : IR (KBr. DRIFTS): $v$ 3213. 2953. 2909. 2876. 2359. 2261. 2039, 1948, 1894 , $1710(\mathrm{C}=\mathrm{C}) .1601 .1573 .1461 .1414,1335,1237,1237$. 1196. 1148. 1098. 1071, 1007, 818. $719 \mathrm{~cm}^{-1}$. UV-vis (THF): $\lambda_{\max } \mathrm{nm}(\varepsilon) 269\left(1.04 \times 10^{5}\right)$. Anal. Calcd for $\left(\mathrm{C}_{20} \mathrm{H}_{27} \mathrm{Si}_{2} \mathrm{BCl}_{2}\right)_{37}:$ C. $59.27 ; \mathrm{H}$. 6.71. Found: C. 60.18: $\mathrm{H}$, 6.87. The excitation and fluorescence emission spectra in THF solution as well as TGA thermogram are described in Result and Discussion.

A dark brown viscous gel $3 f(1.01 \mathrm{~g} .65 \%)$ was obtained from 1 (1.00 g. $4.06 \mathrm{mmol})$ and butyldichloroborane (2f) (1.0 M/hexane. $4.06 \mathrm{~mL} .4 .06 \mathrm{mmol}$ ): $M_{w} / M_{n}=3.720 / 1,910$ $(\mathrm{PDI}=1.95) ;{ }^{1} \mathrm{H}$ NMR $\left(\mathrm{CDCl}_{3}, 400 \mathrm{MHz}\right): \delta 0.59(\mathrm{q}, 6 \mathrm{H})$, 0.88 (t. 9H). $1.20-1.25$ (m. 9H), 1.55 (d. 2H). 1.86 (t. $2 \mathrm{H})$. 5.30 (s. $2 \mathrm{H}), 6.16(\mathrm{~m} . \mathrm{lH}):{ }^{13} \mathrm{C}$ NMR $\left(\mathrm{CDCl}_{2}, 100 \mathrm{MHz}\right): \delta$ $2.66 .6 .61,7.46 .13 .97,22.68,26.96,29.70,30.29$. 139.63, 140.00, 141.04. 141.42: ${ }^{2} \mathrm{Si}$ NMR $\left(\mathrm{CDCl}_{3} .99 \mathrm{MHz}\right): \delta$ 0.00. 19.74: ${ }^{11} \mathrm{~B}$ NMR $\left(\mathrm{CDCl}_{3} .160 \mathrm{MHz}\right): \delta \cdot 2.49$; IR (neat): $v 3290.2953 .2911,2875,2733.2359 .2150,2041$, $1709(C=C) .1574,1460.1415,1364,1260,1089,1008$. 859. 805. $722 \mathrm{~cm}^{-1}$. UV-vis (THF): $\lambda_{\max } \operatorname{nm}(\varepsilon) 268(7.65 \times$ $\left.10^{4}\right)$. Anal. Calcd for $\left(\mathrm{C}_{18} \mathrm{H}_{31} \mathrm{Si}_{2} \mathrm{BCl}_{3}\right)_{n}: \mathrm{C} .56 .11 ; \mathrm{H}, 8.11$. Found: C. 57.20, H, 8.36. The excitation and fluorescence emission spectra in THF solution as well as TGA thermogram are described in Result and Discussion.

Acknowledgment. This work was supported by the Korea Science and Engineering Foundation (Project No. KOSEF R05-2001-000-00192-0). We thank Professor Yong-Rok Kim at Yonsei University, Seoul, Korea for taking the electronic spectra of the oligomers and also helpful discussions.

\section{References}

1. Ohshita. J.: Kunai, A. Acta Polym 1998, 19. 379

2. Bréfort. I. L.: Corriu. R. J. P.: Gerbier. Ph.: Guérit1. C.: Henner. B J. L.: Tean. A.: Kulhmann. Th. Garnier. F.: Yassar. A. Organometallics 1992. 11. 2500.

3. Corriu. R. J. P. Gerbier. Ph.: Guérin, C.; Henner. B.; Fourcade, R. J. Onganomet. Chent 1993. 419,111

4. Kwak. Y.-W; Lee, K.-K; Cha, S.-H; Lee, S.-K; Lee. I.-S.: Park. Y.-T: Lee. J: Yoh. S.D.: Kim. W.S. Bull Korean Chem. Soc. 2003. 24. 479

5. Seo. I. K.: Park. Y. T.: Kim. Y.-R. Bull. Konan Chem. Soc, 1999. 20.677 .

6. Bae. J. Y.: Kim. Y.-R: Park. Y. T. Bull. Korew Chem. Soc. 2000. 21.831 .

7. Hwang. I.-W.: Song. N. W.: Kim. D.: Park. Y. T.: Kim. Y.R. $J$. Polym. Sci. Pan B: Polym. Phus. 1999.37.2901. 
8. Choi. S. H.: Hwang. I.-W.: Kim. S. H.: Park. Y. T.: Kim. Y.-R. $J$. Pohm. Sci. Part B: Pohm. Phys. 2002. to. 1298.

9. Manuel, G.; Weber W. P. Boukherroub. R. Afain Group Met. Chem. 1996, 19. 263.

10. Brook: M. A. Silicon in Organtic, Organonetallic, and Polvmer Chemishy: John Wiley \& Sons. Inc.: New York. 2000.

11. The Chemishy of Organic Silicon Componds: Rappoport. Z: Apeloig. Y.. Eds.: John Wiley \& Sons: Chichester. UK. 1998. Vol. 2: Ihid: Patai, S.: Rappoport. Z.. Eds.: 1989; Vol. 1.

12. Zhang, $X$; Zhou, Q: Weber W. P.: Horvath, R. F; Chan, T. H: Manuel G. Afacronolecules 1988. 21. 1563.

13. Kim. E. J.: Park. J. W.: Kim. Y.-R.: Park. Y. T. Bull. Korem Chem. Soc. 2003. 24. 484

14. Pelter. A.: Smith. K.: Brown. H. C. Borane Reagents: Academic Press: London, 1988.

15. Chujo, Y.: Tomita, I. Saegusa, T. Macromolecules 1990, 23.687.

16. Chujo Y: Tomita. I.: Hashiguchi, Y.: Saegusa, T. Macromolecules 1992. 25.33.
17. Matsumi. N.: Nakia. K.: Chujo. Y. J. Am. Chem. Soc. 1998. 120. 5112.

18. Matsumi. N.: Miyata, M.: Chujo, Y. Macronolecules 1999, 32. 4467.

19. Boukherroub, R.: Manuel. G. J. Organomet Chem. 1993. $+60,155$.

20. Odian1. G. Principles of Polunerization. 3rd ed.: Tohn Wiley \& Son1s: New York. 1991.

21. Pretsch. E.: Bühlmant1. P.: Affolter. C. Structwe Detemination of Organic Conpoumds. Tables of Spectral Data, 3rd ed.; SpringerVerlag: Berlin, 2000.

22. Bellamy, L. J. The Infra-red Spectra of Complex Holecules. $3 \mathrm{rd}$ ed.: Chapman and Hall: London. 1975.

23. Matsumi. N.: Kotera. K.: Chujo. Y. Hacromolecules 2000. 33. 2801.

24. Barashtiov, N. N.: Gunder, O. A. Fluorescent Polnters: Ellis Horwood: New York, 1994.

25. Armarego, W. L. F.: Perrin, D. D. Purification of Laboratory Chemicals, 4th ed: Butterworth-Heinemann: Offord. 1996. 